\title{
Polycyclic Aromatic Hydrocarbons and Suspended Materials in a Semi-urbanized Tidal Creek after an Historic Flood Event and Implications for Water Quality Monitoring
}

\author{
Barbara A. Beckingham ${ }^{1,2^{*}}$, Michael Shahin ${ }^{1}$, Kathryn Ellis $^{2}$, and Timothy J. Callahan ${ }^{1,2}$ \\ AUTHORS: ${ }^{1}$ Department of Geology and Environmental Geosciences, College of Charleston, 66 George Street, Charleston, SC 29424 \\ USA. ${ }^{2}$ Master of Science in Environmental Studies Program, College of Charleston, 66 George Street, Charleston, SC 29424, USA. \\ *beckinghamba@cofc.edu
}

\begin{abstract}
Tidal creeks transport both dissolved and particulate natural organic carbon materials and contaminants, connecting land-based activities with estuarine surface waters. It is important to characterize these materials in tidal creeks because it provides insights as to their origins and potential for ecosystem impacts. Surface water samples were collected from Bull Creek, Charleston, SC, a semi-urbanized tidal creek wetland, on five sampling dates from fall 2015 to spring 2016 to measure total suspended solids (TSS), turbidity, dissolved organic carbon (DOC), SUVA 254 (specific absorbance as an indicator of aromaticity of DOC), and total water concentrations of polycyclic aromatic hydrocarbons (PAHs), a ubiquitous class of hydrophobic organic contaminants of concern. Stream discharge was also measured to allow an estimation of material flux. One of the sampling dates captured these parameters following a historic rainfall related to Hurricane Joaquin in October 2015, and therefore the aim of the present study is to characterize the sources and to quantify the transport of carbonaceous materials and PAHs in Bull Creek, with a focus on the response to this storm event. The quality of suspended solids and DOC were different following the October storm event in comparison to the other sampling dates, and they were more terrestrially derived as shown by shifts in $\mathrm{SUVA}_{254}$ and correlations between TSS and turbidity. Elevated levels of PAHs were detected in Bull Creek after the storm, and diagnostic ratios indicated that additional mixed sources were mobilized by the event. Combining the measures of both carbonaceous material quality and PAH profile contributed to a better understanding of the sources to the tidal creek. Shifts in PAH sources and suspended materials have implications for PAH toxicity to aquatic life, as well as for the appropriate approach to water quality monitoring. Future work should aim to develop relationships between discharge, suspended materials, and PAHs to facilitate more continuous monitoring of material transport in tidal creeks, especially during storm events, which have a strong influence on water quality.
\end{abstract}

\section{INTRODUCTION}

Tidal creeks are the capillaries that link land and sea in estuarine systems, where materials may be readily exchanged and processed. They can be highly productive ecosystems, with profound value as cultural, recreational, and economical resources. However, land use and land cover change are impacting the integrity of these unique systems by changing hydrology and point and non-point source pollution pressures (Holland et al., 2004; Sanger et al., 2015; Schueler, 2000). Urban land use can lead to release of a variety of pollutants of concern into the environment, including heavy metals, nutrients, fecal coliform bacteria, and organic chemicals. Contaminants released to air or on land may accumulate in soils and on roadways and buildings during dry periods and then be flushed into local waterways with stormwater (Krein \& Schorer, 2000; Ngabe et al., 2000; Diamond et al., 2000).

Polycyclic aromatic hydrocarbons (PAHs) are one class of organic contaminants of concern and are a leading threat to aquatic life in urban environments (Van Metre and Mahler, 2005). Both natural and anthropogenic sources of PAHs are observed in the environment, including forest fires, fossil fuels, and coal tar sealants that leach from roofs and roadways (Van Metre and Mahler, 2010). A majority of PAH compounds are known or probable carcinogens, in addition to having other acute and chronic toxic effects to both human and ecological receptors (ATSDR, 1995). Sixteen US EPA priority PAHs are typically monitored in the environment and include compounds with structures containing two to 
six fused aromatic carbon rings. This range in molecular size imparts differences in the physicochemical properties among PAH molecules; for instance, water solubility ranges over 3 orders of magnitude, from $30 \mathrm{mg} / \mathrm{L}$ for naphthalene to $<1 \mu \mathrm{g} / \mathrm{L}$ for perylene (Schwartzenbach et al., 2003). Larger PAH compounds with lower water solubility are more hydrophobic and have a stronger tendency to sorb to lipid or organic-rich phases, such as sediments or dissolved organic carbon (DOC). Several studies have found direct associations between DOC or total suspended solids with transport of, for example, PAHs, mercury and other metals (Cai et al., 1999; Foster et al., 2000; Journey et al., 2012; Kirchner et al., 2011; Nasrabadi et al., 2016; Schwientek et al., 2013). Highflow events are major contributors to DOC and suspended sediment loads (Brown et al., 2014; Hinton et al., 1997) and to associated releases and transport of PAHs in rivers (Foster et al., 2000; Schwientek et al., 2013). Previous investigations have found sediments in stormwater ponds and tidal creeks in South Carolina to be impacted by PAHs, including Bull Creek, the location of the present study (Garner et al., 2009; Sanger et al., 1999; Weinstein et al., 2010).

Understanding the chemical properties of the suspended and dissolved material in streams can provide information about sources and system dynamics. For example, the aromaticity of the DOC matrix is indicative of its origin and biogeochemical activity (Weishaar et al., 2003). SUVA ${ }_{254}$ is a simple surrogate indicator of the aromaticity of DOC. Allochthonous materials (with terrestrial origin) have been associated with higher $\mathrm{SUVA}_{254}$ values relative to autochthonous material (with in-stream origin), such as algae, in streams (Weishaar et al., 2003). The organic matter content of particulate material may also indicate the source by providing a relative measure of organic and mineral composition. Further, analysis of the relative concentrations of PAH compounds in water samples is an approach used to fingerprint PAH sources (Yunker et al., 2002). Liu et al. (2013) used PAH distribution patterns and diagnostic ratios to differentiate ongoing point source contamination from diffuse background contamination in contrasting river catchments.

The objective of the present study is to characterize the loading of PAHs and carbonaceous matter in Bull Creek, a semi-urbanized tidal creek in Charleston, SC, with a specific look at changes after a historic flood event in October 2015. This flood event affected a large part of South Carolina after historic rainfall fell between October 1 and 5, 2015. Record discharges were recorded at river gages across the state (Feaster et al., 2015). The maximum stage of the Ashley River recorded at a gage site adjacent to Bull Creek (USGS 021720869) following the storm event was $4.3 \mathrm{~m}$ ( 14 feet), which at that time was the second highest stage recorded at that site in its period of record since 1992. We collected data on PAHs, total suspended solids and their organic matter content, DOC and aromaticity, and stream discharge, in addition to general water quality characteristics, on four other sampling dates over the period September 2015 to April 2016 for comparison. We use the totality of the information provided by these measures to better understand sources to the tidal creek and to work toward improving water quality monitoring approaches.

\section{METHODS}

\section{SITE DESCRIPTION}

Bull Creek, a small tidal creek tributary watershed ( 778 ha) of the Ashley River near Charleston, SC, was chosen as the study site. The Bull Creek watershed was digitized using United States Geological Survey (USGS) elevation derivatives for national applications (EDNAs) map information. NOAA 2010 Coastal Change Analysis Program (C-CAP) Land Cover Atlas data were used to determine the percent of land use distribution (e.g., developed, forested, and wetlands). Watershed location, delineation, and land use is illustrated in Figure 1A, B. The sampling location is also shown (star; $32^{\circ} 49^{\prime} 38^{\prime \prime} \mathrm{N}, 80^{\circ} 01^{\prime} 44^{\prime \prime} \mathrm{W}$ ). Additionally, ArcGIS software tools were used to delineate the watershed upstream of the sampling location and to categorize land use (Figure 1B). The upstream watershed area of $\sim 430$ ha delineated by ArcGIS digital elevation modeling extends beyond the EDNA watershed boundaries, but upstream land use distribution followed the pattern of the entire watershed. The watershed is dominated by low- and medium-density development but also has some intact wetlands. Bull Creek watershed has a reported impervious cover of 38\% (Sanger et al., 2015).

\section{FIELD SAMPLING AND LABORATORY ANALYSES}

Sampling dates and schedule are shown in Table 1. Sampling was conducted on five dates, with samples spaced over the course of the day between 9 a.m. and 5 p.m. and at different stages of the tidal cycle. Bull Creek exhibits a semidiurnal tidal pattern, with two high tides and two low tides

Table 1. Sampling scheme and number of samples (N)

\begin{tabular}{|cccc|}
\hline Date & $\underline{\text { Tidal Cycle }}$ & \multicolumn{2}{c|}{ Sample Type and N } \\
\multirow{3}{*}{$9 / 22 / 15$} & Fampled & TSS/PAH & N, Ebb/Flood \\
& Flood & TSS & $8 / 0$ \\
& & PAH & $0 / 0$ \\
\hline \multirow{2}{*}{$10 / 9 / 15$} & Ebb \& Flood & TSS & $3 / 1$ \\
& & PAH & $3 / 1$ \\
\hline \multirow{2}{*}{$1 / 25 / 16$} & Ebb & TSS & $4 / 0$ \\
& & PAH & $3 / 0$ \\
\hline $3 / 24 / 16$ & Ebb \& Flood & TSS & $3 / 1$ \\
& & PAH & $2 / 1$ \\
$4 / 11 / 16$ & \multirow{2}{*}{ Ebb \& Flood } & TSS & $4 / 3$ \\
& & PAH & $2 / 2$ \\
\hline
\end{tabular}



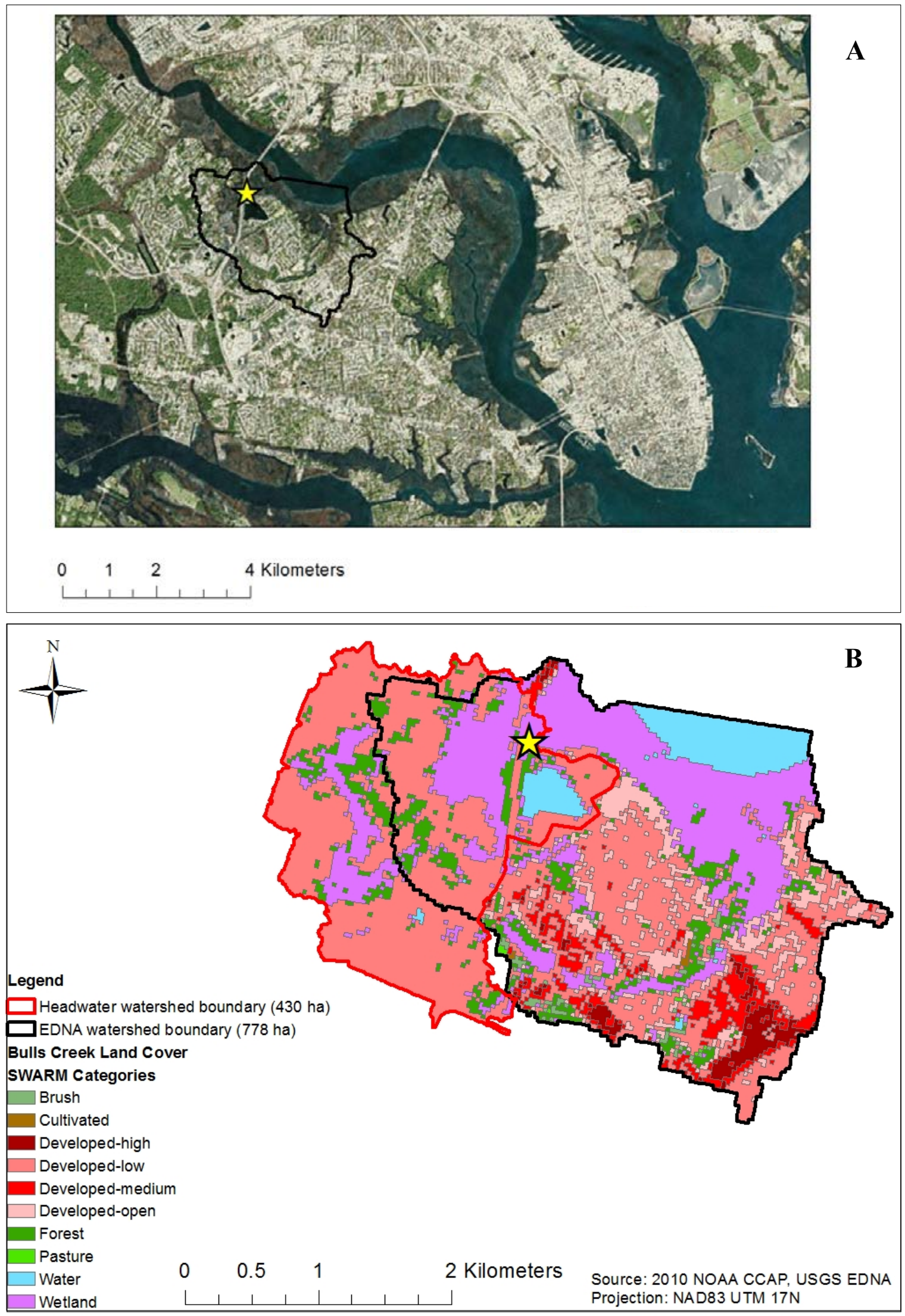

Figure 1. A. Location of the study site in Bull Creek adjacent to the Ashley River near Charleston, SC, with the USGS EDNA watershed shown in black outline. The sampling site within Bull Creek is shown with a star $\left(32^{\circ} 49^{\prime} 38^{\prime \prime} \mathrm{N}, 80^{\circ} 01^{\prime} 44^{\prime \prime} \mathrm{W}\right)$. B. Watershed delineation and land use classification according to the USGS EDNA map system (black; area 778 ha), additionally with the watershed area delineated upstream of the sampling location by ArcGIS (red; area $430 \mathrm{ha}$ ). 
over a lunar day ( 24 hours 50 minutes). The maximum depth of the channel transect over the tidal range was between $2.2 \mathrm{~m}$ and $4.0 \mathrm{~m}$ during the sampling dates. Antecedent precipitation data were acquired from the National Climate Data Center (ncdc.noaa.gov) at a local gage site (\#US1SCCR0087).

Stream discharge, turbidity, and general water quality parameters were measured in the field. Discharge measurements were obtained every 30-60 minutes using a Teledyne $\mathrm{RD}$ Instruments acoustic Doppler current profiler (ADCP) (Ellis et al., this issue). The timing of these measurements was normalized to high tide slack (when discharge is negligible as the creek current switches direction between flood and ebb), which typically occurred about 40 minutes after high tide (the maximum stage of the creek). The ADCP was attached to the back of a kayak and pulled across the width of Bull Creek, collecting water velocity and depth data that are used to calculate average discharge. Two optical backscatter sensors were used to measure the turbidity (cloudiness) of the water: a Thermo-Scientific Orion Aquafast handheld portable turbidity meter and a YSI Multiparameter Water Quality Sonde (6600 V2). These two instruments measure turbidity at different angles of light scatter. The former detects light at a $180^{\circ}$ angle with color compensation, while the later detects light at a $90^{\circ}$ angle without color compensation. The handheld turbidity meter was used on sampling dates $9 / 22 / 15$ and $10 / 9 / 15$, and the sonde was used on $1 / 25 / 16$, while both instruments were used to collect turbidity data on $3 / 24 / 16$ and 4/11/16. A comparison of results for the turbidity meter and sonde on these two dates showed good agreement between the instruments, with the sonde generally indicating slightly higher turbidity but within 1 S.D. of the turbidity meter average (e.g., 3/24 11 am 8.09 \pm 0.66 NTU vs. 8.7 NTU, and 4/11 4 pm 19.24 \pm 0.89 NTU vs. 19.6 NTU). On the dates that both instruments were used, data from the handheld turbidity meter were reported. Temperature, $\mathrm{pH}$, salinity, and conductivity were measured with the YSI.

Water samples were collected at elbow depth $(\sim 0.3$ $\mathrm{m})$ from a dock or kayak in coordination with discharge measurements to determine the $\mathrm{PAH}$ concentrations and to characterize the dissolved and suspended matter. A flow chart depicting the sample analysis is shown in Figure 2. Whole water samples collected in $1 \mathrm{~L}$ amber glass bottles were processed to quantify the total suspended solids, organic matter content of the solids, DOC concentration, and aromaticity of the DOC $\left(\mathrm{SUVA}_{254}\right)$. Total suspended solids were determined as the dry mass of the particulates captured on a GF/F glass fiber filter $(0.7 \mu \mathrm{m}$ pore size) after drying in an oven at $105^{\circ} \mathrm{C}$ to constant weight. The organic matter content of the solids was determined by loss on ignition after combusting the filter at $450^{\circ} \mathrm{C}$ for 4 hours (ASTM, 2014). The filtrate was acidified to $\mathrm{pH} \mathrm{2-3}$ with $1 \mathrm{~N} \mathrm{HCl}$, purged in a sonication bath, and analyzed for DOC using a Shimadzu elemental analyzer (TOC-VPN) against calibration standards

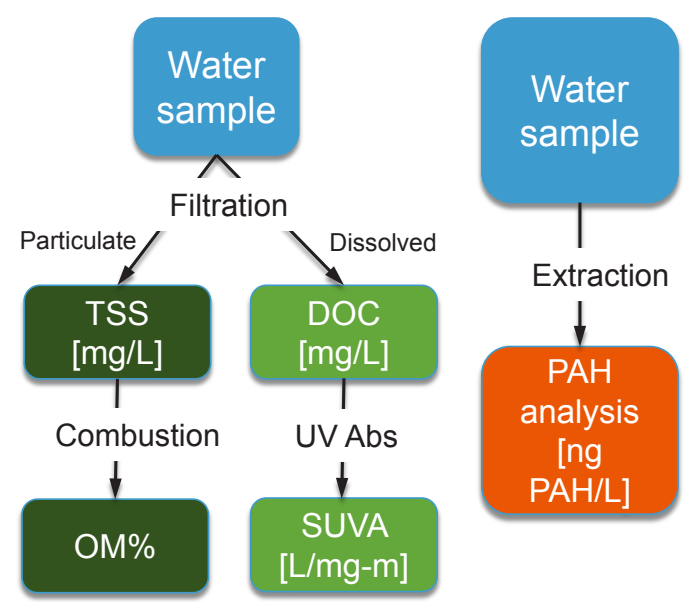

Figure 2. Sample analysis flowchart. Abbreviations: TSS = total suspended solids, $\mathrm{OM}=$ organic matter, $\mathrm{DOC}=\mathrm{DOC}, \mathrm{SUVA}_{254}=$ specific UV absorbance, and PAHs = polycyclic aromatic hydrocarbons.

prepared with potassium hydrogen phthalate $\left(\mathrm{C}_{8} \mathrm{H}_{5} \mathrm{KO}_{4}\right)$. The specific UV absorbance at $254 \mathrm{~nm}$ wavelength $\left(\mathrm{SUVA}_{254}\right)$ was determined on an unacidified filtrate using a UV-Vis spectrophotometer (Thermo Scientific Evolution 220). SUVA $_{254}$ was determined as the absorbance of the sample normalized to its DOC content (Weishaar et al., 2003).

Whole water samples for PAH analysis were collected in 2 L glass bottles with Teflon-lined caps and kept refrigerated until sample processing. The samples for PAHs were collected on four of five sampling dates (Table 1). Liquidliquid extraction was performed in the $2 \mathrm{~L}$ bottles by adding $15 \mathrm{~mL}$ of hexane and gently shaking on a horizontal shaker table for 24 hours (USEPA, 1996). The samples were allowed to settle for several hours to allow the layers to separate, as emulsions were common in the relatively high-DOC water matrix. Hexane was recovered by directly pipetting the top hexane layer off the bottle or with the aid of a separatory funnel. A second liquid-liquid extraction with hexane was performed by hand-shaking for 2 minutes. The recovered hexane layers were pooled for each sample, dried with sodium sulfate, and condensed to $<350 \mu \mathrm{L}$. Blank DI water extractions were also performed to ensure no laboratory background or cross-contamination. PAHs were analyzed by an Agilent Technologies gas chromatograph with mass spectrometer detection in selective ion monitoring mode (GC-MS; model 7890A GC with directly coupled model 5975C MS). Separation was performed following injection and introduction of the sample in pulsed splitless mode onto an Agilent DB-XLB column $(0.18 \mu \mathrm{m}, 20 \mathrm{~m}$ x $0.180 \mathrm{~mm}$ I.D.), with $\mathrm{He}$ carrier gas $(0.6 \mathrm{~mL} / \mathrm{min})$ and stepped oven temperature ramps from $55^{\circ} \mathrm{C}$ to $310^{\circ} \mathrm{C}$ during the 46 minute analytical run. Twelve PAHs were quantified against their ${ }^{13} \mathrm{C}$-labelled internal standards by an isotope dilution method (Boden and Reiner, 2004), including: three-member ring compounds, acenaphthylene (ANY), acenaphthene (ACE), fluorene (FLN), phenanthrene (PHE), and anthracene (ANT); 
four-member ring compounds, fluoranthene (FTH), pyrene (PYR), benzo(a)anthracene (BaA), and chrysene (CHR); and five-member ring compounds, benzo(b)fluoranthene $(\mathrm{BbF})$, benzo(k)fluoranthene $(\mathrm{BkF})$ and benzo(a)pyrene $(\mathrm{BaP})$. The detection limit for each PAH was $1 \mathrm{ng} \mathrm{L}^{-1}$.

\section{CALCULATION OF PARTICLE AND PAH FLUXES}

A full ebb tide was captured with periodic sampling on $10 / 9 / 15,1 / 25 / 16$, and $3 / 24 / 16$. Discharge was measured at least hourly over the course of the ebb tide (PAHs two to three times and TSS three to four times). To calculate flux, TSS and PAH mass concentrations were averaged $\left(C_{a v g}\right.$, mass/L) and multiplied by the total water volume discharged past the sampling point in Bull Creek $\left(V_{\text {total }} \mathrm{L}\right)$ divided by the duration (in hours) of the ebb cycle:

$$
\text { Flux }\left[\frac{\text { mass }}{h r}\right]=\frac{C_{a v g} V_{\text {total }}}{t},
$$

where $V_{\text {total }}$ was determined by integrating the discharge values measured over time. This approach is not flow-weighted and assumes that the surface water sample is representative of the stream cross section.

\section{RESULTS}

\section{ENVIRONMENTAL CONDITIONS}

Water temperature, $\mathrm{pH}$, and conductivity, along with antecedent rainfall data for each of the sampling dates, are shown in Table 2. Of particular note is the dramatic reduction in conductivity in October, which reflects the high volume of freshwater runoff delivered to Bull Creek from the precipitation event related to Hurricane Joaquin (Oct $1-5)$. Water salinity is typically brackish at the site but was classified as freshwater in October 2015.

\section{SUSPENDED MATTER: DISSOLVED AND PARTICULATE}

The concentration and quality of particulate matter and DOC in water samples are shown in Figure 3. Samples collected on October 9, 2015, are plotted separately from the other sampling dates. Total concentration of suspended solids was generally lower in October but with similar organic matter content (Figure 3A,B). In contrast, although the DOC content was at a level consistent with other sampling dates, the $\mathrm{SUVA}_{254}$ measurement was elevated (Figure 3C,D). The higher $\mathrm{SUVA}_{254}$ values in October are indicative of a more aromatic, terrestrial source of DOC.

Although the organic matter content of suspended particulates was consistent across sampling dates (Figure 3B), the correlation between turbidity and TSS deviated in October (Figure 4). Turbidity is measured by optical light scattering, and the characteristics of the particles in solution that affect light scattering include the general type and, in particular, the particle size, geometry, density, and color (Gippel, 1995; Rügner et al., 2013). The offset correlation indicates that some fraction of the suspended material measured as TSS in the water samples following the October 2015 storm event scatters light differently and therefore has a different quality.

Table 2. Precipitation and water condition parameters for sampling dates (S.D. of average measures in parentheses)

\begin{tabular}{|c|c|c|c|c|c|}
\hline \multirow[t]{2}{*}{$\underline{\text { Date }}$} & \multicolumn{2}{|c|}{$\frac{\text { Antecedent }}{\text { precipitation }}$} & \multirow{2}{*}{$\begin{array}{c}\underline{T} \\
\left({ }^{\circ} \mathrm{C}\right)\end{array}$} & \multirow[t]{2}{*}{$\mathrm{pH}$} & \multirow{2}{*}{$\frac{\text { Conductivity }}{(\mathrm{mS} / \mathrm{cm})}$} \\
\hline & Period & $(\mathrm{mm})$ & & & \\
\hline \multirow{2}{*}{$9 / 22 / 15$} & $10 \mathrm{~d}$ & 1.8 & 26.0 & 7.0 & \multirow{2}{*}{$26.7(3.8)$} \\
\hline & $5 \mathrm{~d}$ & 0.0 & $(0.8)$ & $(0.1)$ & \\
\hline \multirow{2}{*}{$10 / 9 / 15$} & $10 \mathrm{~d}$ & 413.3 & 21.8 & 6.1 & \multirow{2}{*}{$0.9(0.5)$} \\
\hline & $5 \mathrm{~d}$ & 42.4 & $(0.9)$ & $(0.2)$ & \\
\hline \multirow{2}{*}{$1 / 25 / 16$} & $10 \mathrm{~d}$ & 91.7 & 9.5 & 7.2 & \multirow{2}{*}{$8.4(5.1)$} \\
\hline & $5 \mathrm{~d}$ & 39.7 & $(0.8)$ & $(0.2)$ & \\
\hline \multirow{2}{*}{$3 / 24 / 16$} & $10 \mathrm{~d}$ & 4.8 & 19.5 & 5.8 & \multirow{2}{*}{$14.7(1.2)$} \\
\hline & $5 \mathrm{~d}$ & 2.3 & $(0.7)$ & $(0.8)$ & \\
\hline \multirow{2}{*}{$4 / 11 / 16$} & $10 \mathrm{~d}$ & 26.1 & 17.8 & 5.7 & \multirow{2}{*}{$16.4(3.1)$} \\
\hline & $5 \mathrm{~d}$ & 1.0 & (1.4) & $(0.6)$ & \\
\hline
\end{tabular}
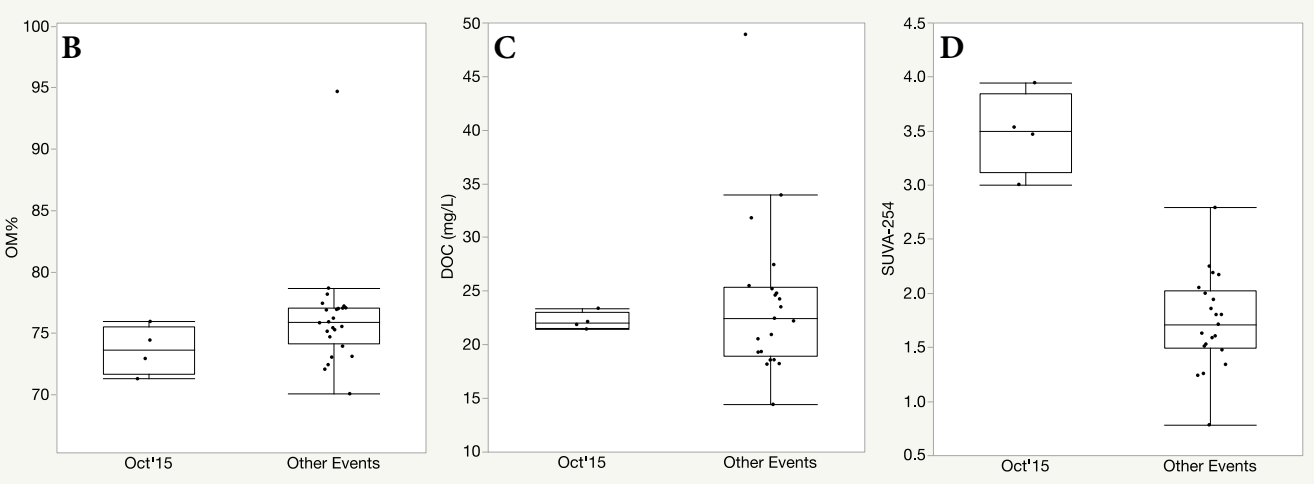

Figure 3. Box and whisker plots show data points, quartiles, and outliers for (A) total suspended solids (TSS), (B) suspended solids organic matter (OM) content, (C) dissolved organic carbon (DOC), and (D) specific absorbance of DOC (SUVA ${ }_{254}$ ) in units of $\mathrm{L} \mathrm{mg}^{-1} \mathrm{~m}^{-1}$. Samples taken on 10/9/15 are plotted separately from the other dates. 


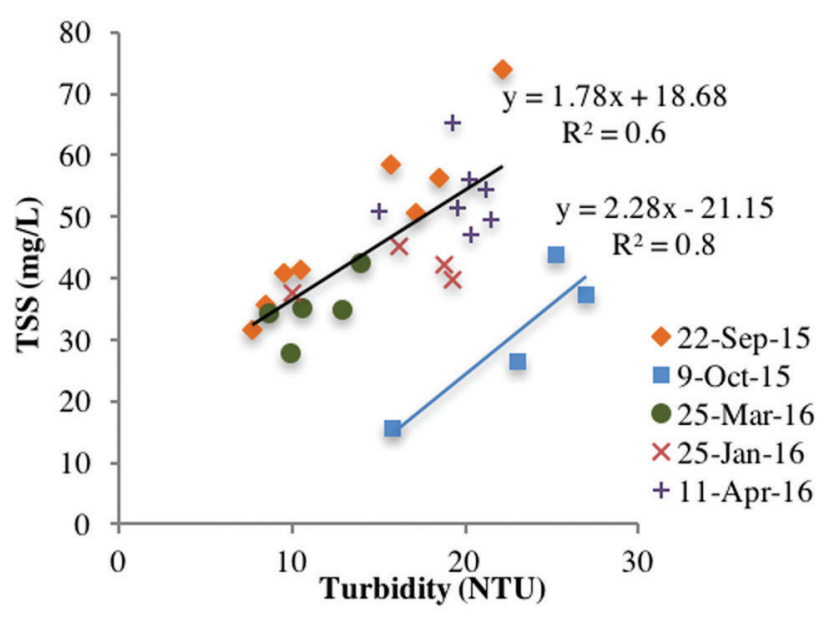

Figure 4. Total suspended solids (TSS) versus turbidity for water samples collected on $10 / 9 / 15$, in contrast to the other sampling dates.

\section{POLYCYCLIC AROMATIC HYDROCARBONS}

The total concentration of 12 PAHs (PAH-12) in water was higher in October 2015 compared to the other sampling events (Figure 5). The concentrations of PAHs expressed on a particle mass basis indicated an even larger difference (data not shown), since the TSS concentration was lower in October. The distribution pattern of PAHs showed a larger contribution of lower molecular weight three-ring PAHs (ANY, ACE, FLN, PHE, ANT) in October 2015 (45\% of the total PAH-12 concentration) compared to January, March, and April 2016 (0\%, 0\%, and 4\% of the total PAH12 , respectively). The concentrations of PAHs in all samples analyzed were below the ecological risk assessment screening values for surface waters for the southeastern United States (US EPA, 2015).

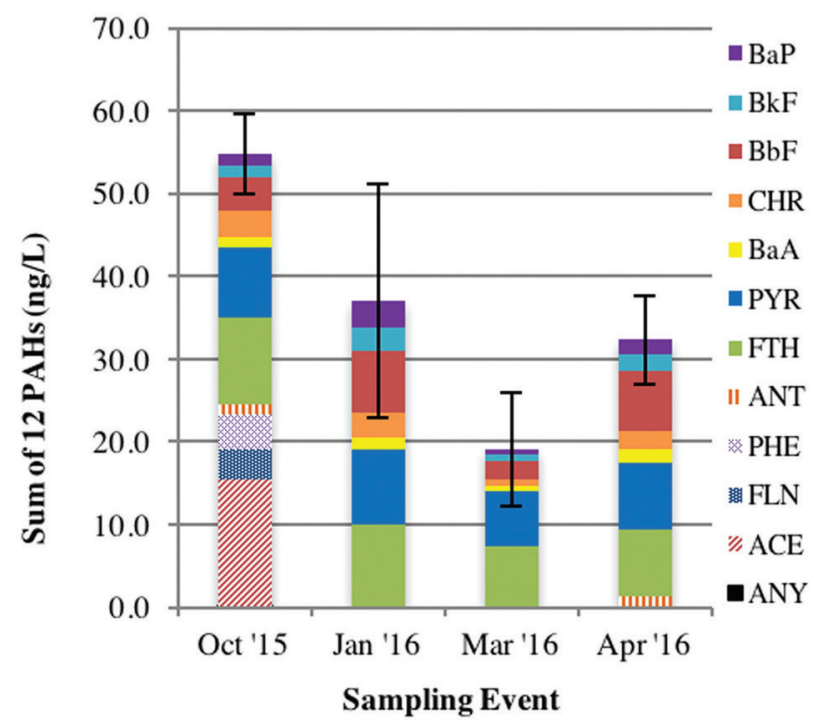

Figure 5. Concentration of $12 \mathrm{PAHs}$ in whole water samples from Bull Creek, SC. Error bars show \pm 1 S.D. of the mean for the sum of PAHs.
Diagnostic ratios of PAH compounds were used to further distinguish sources as either petroleum or combustion derived, following Yunker et al. (2002) (Figure 6). The ratios of $\mathrm{FTH} / \mathrm{FTH}+\mathrm{PYR}$ and $\mathrm{BaA} / \mathrm{BaA}+\mathrm{CHR}$ were applied due to the robustness of these ratios and the consistent detection of these compounds in whole water samples in the present study. Further, since these PAHs are hydrophobic and are primarily associated with particles (octanol-water partition coefficient, $\log \mathrm{K}_{\mathrm{OW}}>5$ ), it is more appropriate to apply the diagnostic ratios that are established for sediments and suspended particles. The diagnostic ratios cross-plot indicates a combination of biomass, coal, and petroleum combustion, with a stronger mixed-sources signal indicated by the lower $\mathrm{BaA} / \mathrm{BaA}+\mathrm{CHR}$ ratio for the October 2015 samples (Figure 6).

\section{FLUXES OF PAHS AND CARBONACEOUS MATERIALS}

The total cumulative discharge volume of the $\sim 6$ hour ebb tides captured on $10 / 9 / 15,1 / 26 / 16$, and $3 / 24 / 16$ were $291,800 \mathrm{~m}^{3}, 287,200 \mathrm{~m}^{3}$, and $137,100 \mathrm{~m}^{3}$, respectively. The average flood and ebb discharge at this site is reported in Ellis et al. (this issue). The high discharge measured in January is attributed to the full moon on 1/25/16 and recent precipitation ( $5 \mathrm{~d}$ antecedent precipitation was similar for January and October sampling dates, Table 1). The average hourly fluxes of PAHs, DOC, TSS and particulate organic matter (POM, calculated from TSS and OM\%) estimated for these dates are shown in Table 3. The fluxes reported are for the ebb tide only at a midpoint within the Bull Creek watershed and therefore do not represent the entire net flux of suspended materials in this watershed.

The average hourly flux of TSS was highest in January, while for PAHs, it was highest in October. This is the direct

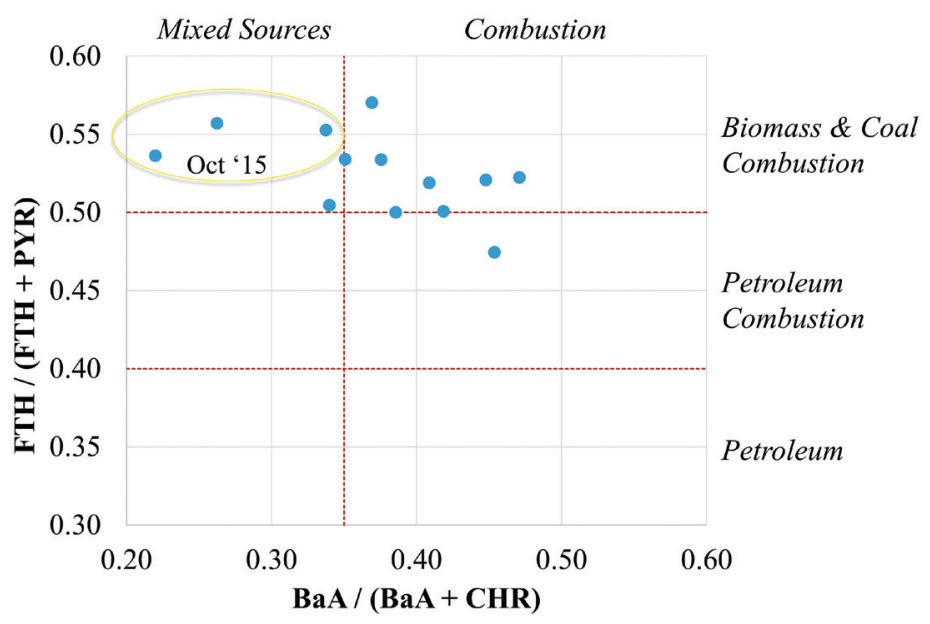

Figure 6. PAH diagnostic ratios can indicate sources of contamination, indicated in italics along the figure margins. Mixed sources include petroleum and combustion. Samples on 10/9/15 are encircled. 
Table 3. Average hourly flux of materials calculated by grab samples and discharge measurements over an ebb tide in Bull Creek, SC.

\begin{tabular}{|lcccc|}
\hline Date & $\begin{array}{c}\text { DOC } \\
(\mathbf{k g} / \mathbf{h r})\end{array}$ & $\begin{array}{c}\text { TSS } \\
(\mathbf{k g} / \mathbf{h r})\end{array}$ & $\begin{array}{c}\text { POM } \\
(\mathbf{k g} / \mathbf{h r})\end{array}$ & $\begin{array}{c}\text { PAHs } \\
(\mathbf{g} / \mathbf{h r})\end{array}$ \\
\hline $10 / 9 / 15$ & 1100 & 1525 & 1143 & 2.7 \\
$1 / 26 / 16$ & 1200 & 1975 & 1520 & 1.8 \\
$3 / 24 / 16$ & 838 & 800 & 610 & 0.5 \\
\hline
\end{tabular}

result of higher concentrations of the materials measured on these respective dates when similarly high discharge was experienced. The range in calculated flux over these three sampling dates was greater for PAHs than TSS. The flux of PAHs measured in October was 1.5 times greater than in January, and six times greater than in March. The lowest flux was observed in March when there was slower mean water velocity and less antecedent precipitation.

\section{DISCUSSION}

Several different measures of water quality collected in the present study indicated a significant alteration of the Bull Creek system in response to the historic flood event in October 2015. In addition to a decrease in salinity from brackish to freshwater, the nature of the suspended particle and DOC load changed, and a different profile of PAHs was mobilized. The precipitation and flooding that followed in October 2015 delivered particulate and dissolved organic material that was likely of terrestrial origin that may not typically be mobilized during smaller rain events (e.g., January 2016) and that was carrying a relatively high load of PAHs.

The PAH distribution pattern in October 2015 shifted toward PAHs with lower molecular weight (Figure 5) and also indicated mixed sources (Figure 6). These lower molecular weight compounds are relatively more mobile and bioaccessible due to higher water solubility and are capable of exerting an acute narcosis toxicity risk to aquatic organisms (Di Toro and McGrath, 2000). While the mixedsources signal in October may have included both petroleum and combustion sources and is difficult to interpret, the shift suggests a contribution of petroleum combustion products in the water samples, possibly from diesel burning since this variable source falls into the ranges observed for both diagnostic ratios examined (Yunker et al., 2002). A number of major roadways are in the vicinity, including a highway bridge upstream of the study site. The predominance of threering PAHs in October may also suggest that less-weathered sources were mobilized by the flood waters (Vulava et al., 2016). The influx of fresh water to a system can drive the dissolution of low-molecular weight PAHs. In another study in coastal South Carolina, PAHs in runoff and in tidal creeks were also found to be combustion derived and more similar to atmospheric deposition end members than oils (Ngabe et al., 2000). A previous investigation of sediments also concluded that pyrogenic sources predominate in the Bull Creek watershed (Garner et al., 2009). However, the present study highlights the potential for specific combustion source profiles of PAHs to Bull Creek to change depending on the storm event, likely depending on the hydrologic connectivity of the watershed, wetland system, and time of year. Additional characterization of soil, sediment, and atmospheric deposition matrices in the watershed and expansion of the PAH compounds analyzed, including alkylated PAHs, could provide further insight into sources in the watershed.

Sediments accumulate contamination that may be redistributed during storm events, and suspended material reflect the character of the existing in-stream sediment and the overland-derived particulate and dissolved material. The sampling date of 10/9/15 was a week after Hurricane Joaquin, and therefore the state of the system when it was experiencing the greatest flows and inputs following the storm were not captured. Lower TSS concentrations in October than in January may indicate that much of the mobile material in Bull Creek had already been flushed downstream, leaving a post-storm signature that we captured on 10/9. Also, DOC is often correlated with discharge during storm events (Hinton et al., 1997), and therefore the DOC we measured on 10/9 was likely on the falling limb of DOC export. The SUVA ${ }_{254}$ characterization of DOC indicated a difference in the quality of DOC following the October 2015 storm, and changes in the nature of DOC in streams due to storms has been reported in other systems (e.g., Dalzell et al., 2005). More time-discretized monitoring and modeling is required to capture material transport during storm events.

Turbidity monitoring using in situ sensors has been advanced as an important proxy of suspended solids and particle-associated contaminants for the continuous monitoring of water quality, since grab samples cannot fully capture a dynamic system (e.g., Schweintek et al., 2013). However, the use of turbidity as a proxy relies on stability in the correlations, which can shift due to changes in suspended loads following storms (Downing, 2006), as observed in the present study. Interestingly, the OM content of particles does not help describe the differences in suspended matter that would lead to a different turbidity versus TSS correlation. Particle size analysis and coloration are two additional measures that may contribute to a better understanding of changes in backscatter in water samples and that may aid the development of multi-parameter or flow regime-dependent correlations for a system. The storm event in October 2015 may have been an outlier in the TSS versus the turbidity correlation due to sampling timing several days after the storm, following the loss of sediment and contaminant storage from within the tidal creek channel (Schwientek 
et al., 2017). However, this level of understanding (e.g., outlier determination, or multi-parameter correlations) would require a longer data record and more extensive parameterization than are presently available for Bull Creek. Additional sampling and characterization may also uncover seasonal patterns that need to be accounted for, such as changes in terrestrial carbon and $\mathrm{PAH}$ sources and primary in-stream productivity and plankton assemblages (Osburn et al., 2015; Reed et al., 2015). While TSS versus turbidity correlations have been established for tidal creek salt marsh systems in other studies (Suk et al., 1998), it is possible that the impact of urbanization and stormwater complicates this approach, especially in smaller watersheds. This presents an opportunity for further study.

In conclusion, changes in both carbonaceous matter and $\mathrm{PAH}$ profile during storm events present a challenge for water quality monitoring in tidal creeks since the dynamics are difficult to capture with routine sampling approaches. These changes are important to understand due to the potential concomitant alteration of contaminant bioavailability and toxicity. Hydrology data collected in these systems, coupled with water quality monitoring results, will provide better data to guide management and regulatory decisions. Discharge conditions for ebb and flood tides in tidal creeks have been shown to be asymmetric (e.g., Ellis et al, this issue), and therefore both the duration and relative discharge of ebb and flood tides need to be accounted for to determine the net flux of materials. An additional aspect to consider is the accuracy of loading models, such as those for total maximum daily load (TMDL) predictions. Future work should aim to explore the parameterization needed to establish rating curves for tracking changes in water quality and contaminant transport in tidal creeks.

\section{ACKNOWLEDGEMENTS}

This study was supported by startup funding for B. Beckingham from the College of Charleston (CofC). South Carolina Department of Natural Resources is thanked for the use of the ADCP, and several CofC student research participants are acknowledged for their contributions to data collection (Emily Townsend, William Vesely, Jessica Woodruff, Austin Morrison, Kimberly Sitta, Hayley Bell, Devon Rutledge, and Mikala Randich). We would also like to thank Vijay Vulava and anonymous reviewers for comments on the manuscript.

\section{LITERATURE CITED}

ASTM D2974-14, Standard Test Methods for Moisture, Ash, and Organic Matter of Peat and Other Organic Soils, ASTM International, West Conshohocken, PA. 2014, www.astm.org.
ATSDR 1995. Toxicological Profile For Polycyclic Aromatic Hydrocarbons. U.S. Department of Health and Human Services, Agency for Toxic Substances and Disease Registry, Atlanta, GA. August 1995.

Boden, A.R. and Reiner, E.J., 2004. Development of an isotope-dilution gas chromatographic-mass spectrometric method for the analysis of polycyclic aromatic compounds in environmental matrices. Polycycl. Aromat. Comp. 24, 309-323.

Brown, M.M., Mulligan, R.P., and Miller, R.L., 2014. Modeling the transport of freshwater and dissolved organic carbon in the Neuse River Estuary, NC, USA following Hurricane Irene (2011). J. Estuar. Coast. Shelf Sci. 139:148-158.

Cai, Y., Jaffe, R. and Jones, R., 1999. Interactions between dissolved organic carbon and mercury species in surface waters of the Florida Everglades. Appl. Geochem. 14:395407.

Dalzell, B.J., Filley, T.R., and Harbor, J.M. 2005. Flood pulse influences on terrestrial organic matter export from an agricultural watershed. J. Geophys. Res. 110:1-14.

Diamond, M.L., Gingrich, S.E., Fertuck, K., McCarry, B.E., Stern, G.A., Billeck, B., Grift, B., Brooker, D., and Yager, T.D. 2000. Evidence for organic film on an impervious surface: characterization and potential teratogenic effects. Environ. Sci. Technol. 34:2900-2908.

Di Toro, D.M. and McGrath, J.A. 2000. Technical basis for narcotic chemicals and polycyclic aromatic hydrocarbon criteria. II. Mixtures and sediments. Environ. Toxicol. Chem. 19:1971-1982.

Downing, J. 2006. Twenty-five years with OBS sensors: The good, the bad, and the ugly. Cont. Shelf. Res. 26:22992318.

Ellis, K.K., Callahan, T., Greenfield, D.I., Sanger, D., and Robinson, J. In review, this issue. Hydrologic assessments of tidal creeks to inform nutrient management recommendations. J. SC Water Res.

Feaster, T.D., Shelton, J.M., and Robbins, J.C. 2015. Preliminary peak stage and streamflow data at selected USGS streamgaging stations for the South Carolina flood of October 2015 (ver. 1.1, November 2015): U.S. Geological Survey Open-File Report 2015-1201, 19 p., https://dx.doi.org/10.3133/ofr20151201.

Foster, G.D., Roberts, E.C., Gruessner, B., and Velinksy, J. 2000. Hydrogeochemistry and transport of organic contaminants in an urban watershed of Chesapeake Bay (USA). Appl. Geochem. 15:901-915.

Garner, T.R., Weinstein, J.E., and Sanger, D.M. 2009. Polycyclic aromatic hydrocarbon contamination in South Carolina salt marsh-tidal creek systems: Relationships among sediments, biota, and watershed land use. Arch. Environ. Contam. Toxicol. 57:103-115.

Gippel, C.J. 1995. Potential of turbidity monitoring for measuring the transport of suspended solids in streams. Hydrol. Process. 9:83-97.

Hinton, M.J., Schiff, S.L., and English, M.C. 1997. The significance of storms for the concentration and export of 
dissolved organic carbon from two Precambrian Shield sediments. Biogeochem. 36:67-88.

Holland, A.F., Sanger, D.M., Gawle, C.P., Lerberg, S.B., Santiago, M.S., Riekerk, G.H., Zimmerman, L.E., and Scott, G.I. 2004. Linkages between tidal creek ecosystem and the landscape and demographic attributes of their watersheds. J. Exp. Mar. Bio. Ecol. 298:151-178.

Journey, C.A., Burns, D.A., Riva-Murray, K., Brigham, M.E., Button, D.T., Feaster, T.D., Petkewich, M.D., and Bradley, P.M. 2012. Fluvial transport of mercury, organic carbon, suspended sediment, and selected major ions in contrasting stream basins in South Carolina and New York, October 2004 to September 2009: U.S. Geological Survey Scientific Investigations Report 2012-5173, 125 p.

Kirchner, J.W., Austin, C.M., Myers, A., and Whyte, D.C. 2011. Quantifying remediation effectiveness under variable external forcing using contaminant rating curves. Environ. Sci. Technol. 45:7874-7881.

Krein, A., Schorer, M. 2000. Road runoff pollution by polycyclic aromatic hydrocarbons and its contribution to river sediments. Wat. Res. 34:4110-4115.

Liu, Y., Beckingham, B., Rügner, H., Li, Z., Ma, L., Schwientek, M., Xie, H., Zhao, J., and Grathwohl, P. 2013. Comparison of sedimentary PAHs in the rivers Ammer (Germany) and Liangtan (China): Differences between early- and newly-industrialized countries. Environ. Sci. Technol. 47:701-709.

Nasrabadi, T., Ruegner, H., Sirdari, Z.Z., Schwientek, and M., Grathwohl, P. 2016. Using total suspended solids (TSS) and turbidity as proxies for evaluation of metal transport in river water. Appl. Geochem. 68:1-9.

Ngabe, B., Bidleman, T.F., Scott, and G.I. 2000. Polycyclic aromatic hydrocarbons in storm runoff from urban and coastal South Carolina. Sci. Tot. Environ. 225:1-9.

Osburn, C.L., Mikan, M.P., Etheridge, J.R., Burchell, M.R., and Birgand, F. 2015. Seasonal variation in the quality of dissolved and particulate organic matter exchanged between a salt marsh and its adjacent estuary. J. Geophys. Res. 120:1430-1449.

Reed, M.L., DiTullio, G.R., Kacenas, and S.E., Greenfield, D.I. 2015. Effects of nitrogen and dissolved organic carbon on microplankton abundances in four coastal South Carolina (USA) systems. J. Aq. Micro. Ecol. 78:1-14.

Rügner, H., Schientek, M., Beckingham, B., Kuck, B., and Grathwohl, P. 2013. Turbidity as a proxy for total suspended solids (TSS) and particle facilitated pollutant transport in catchments. Environ. Earth Sci. 69:373-380.

Sanger, D.M., Holland, A.F., and Scott, G.I. 1999. Tidal creek and salt marsh sediments in South Carolina coastal estuaries: II. Distribution of organic contaminants. Arch. Environ. Contam. Toxicol. 37:458-471.

Sanger, D., Blair, A., DiDonato, G., Washburn, T., Jones, S., Riekerk, G., Wirth, E., Stewart, J., White, D., Vandiver, L., and Holland, A.F. 2015. Impacts of coastal development on the ecology of tidal creek ecosystems of the US Southeast including consequences to humans. Estuaries and Coasts. 38(Suppl 1):S49-S66.
Schueler, T. 2000. The importance of imperviousness. Watershed Protection Techniques 1(3):100-111.

Schwartzenbach, R.P., Gschwend, P.M., and Imboden, D.M. 2003. Environmental Organic Chemistry, 2nd Edition.

Wiley-Interscience: Hoboken, NJ USA.

Schweintek, M., Rügner, H., Beckingham, B., Kuck, B., and Grathwohl, P. 2013. Integrated monitoring of particle associated transport of PAHs in contrasting catchments. Environ. Poll. 172:155-162.

Schwientek, M., Rügner, H., Scherer, U., Rode, M., Grathwohl, P. 2017. A parsimonious approach to estimate PAH concentrations in river sediments of anthropogenically impacted watersheds. Sci. Tot. Environ. 601-602:636-645.

Suk, N.S., Guo, Q., Psuty, N.P. 1998. Feasibility of using a turbidimeter to quantify suspended solids concentration in a tidal saltmarsh creek. Estuar. Coast. Shelf Sci. 46:383391.

US EPA, 1996. Method 3510C Separatory Funnel LiquidLiquid Extraction. Revision 3. December 1996.

US EPA, 2015. Region 4 Ecological Risk Assessment Supplemental Guidance, Interim Draft. United States Environmental Protection Agency, Superfund Division. Accessed online 7 Sept. 2016. https://www.epa.gov/sites/ production/files/2015-09/documents/r4 era guidance document draft final 8-25-2015.pdf

Van Metre, P.C., Mahler, B. 2005. Trends in hydrophobic organic contaminants in urban and reference lake sediments across the United States, 1970-2001. Environ. Sci. Technol. 39: 5567-5574.

Van Metre, P.C., Mayler, B. 2010. Contribution of PAHs from coal-tar pavement sealcoat and other sources to 40 U.S. lakes. Sci Tot. Environ. 409:334-344.

Vulava, V.M., Vaughn, D.S., McKay, L.D., Driese, S.G., Cooper, L.W., Menn, F-M., Levine, N.S., Sayler, G.S. 2017. Flood-induced transport of PAHs from streambed coal tar deposits. Sci. Tot. Environ. 575:247-257.

Weinstein, J.E., Crawford, K.D., Garner, T.R., Flemming, A.J. 2010. Screening-level ecological and human health risk assessment of polycyclic aromatic hydrocarbons in stormwater detention pond sediments of coastal South Carolina, USA. J. Haz. Mat. 178:906-916.

Weishaar, J.L., Aiken, G.R., Bergamaschi, B.A., Fram, M.S., Fuji, R., and Mopper, K. 2003. Evaluation of specific ultraviolet absorbance as an indicator of the chemical composition and reactivity of dissolved organic carbon. Environ. Sci. Technol. 37:4702-4708.

Yunker, M.B., Macdonald, R.W., Vingarzan, R., Mitchell, R.H., Goyette, D., Sylvestre, S. 2002. PAHs in the Fraser River basin: a critical appraisal of PAH ratios as indicators of PAH source and composition. Org. Geochem. 33:489515 